\title{
THE IMPACT OF FUNCTIONAL LITERACY ON SOCIO-ECONOMIC LIVES OF BENEFICIARIES: A CASE STUDY OF THE AGONA DISTRICT OF GHANA
}

\author{
ARKO, Augustus Daniel \\ Centre for Continuing Education, \\ University of Cape Coast, \\ Ghana \\ asamoagyima@yahoo.com \\ and \\ ADDISON, Kofi \\ Department of Basic Education, \\ University of Education, \\ Winneba, Ghana
}

\begin{abstract}
This paper presents a report on a study which sought to examine the extent of the relationship between participation in the Functional Literacy Programme and improvement in the socioeconomic lives of the beneficiaries of the programme. Data was collected from 100 beneficiaries of the functional literacy classes in the Agona District of Ghana using an Interview Guide on the Impact of Functional Literacy Programme on Beneficiaries (IGIFLPB). The results of the study established a relationship between participation in the functional literacy classes and improvement in social and economic lives of beneficiaries of the programme. The results showed that beneficiaries of the functional literacy classes could read, write and do numerical calculations to some appreciable extent at the time of their completion of the course and this helps them in their trading activities. Furthermore, it was found that beneficiaries of the literacy classes had become conscious of the need to improve upon their health status. The paper makes recommendations for improvement of the Functional Literacy Programme in Ghana.
\end{abstract}

Key Words: functional literacy, formal education, Ghana, reading, writing.

\section{Introduction}

Formal education helps in the development of the individual and society and it is regarded as the key that unlocks the door to development 
(Thompson, 1981). This is because formal education produces people who contribute immensely to the growth and development of society.

Developed and developing countries recognise the fact that formal education is a pre-requisite for growth and development and so they try to provide quality formal education for their citizens. Studies of the more advanced countries notably the United States, Denmark and Japan during the period of their economic growth and development, suggest that there had been a very significant relationship between their economic growth and the quality of formal education provided to their citizens (Thompson, 1981).

The United Nations Declaration of Human Rights of 1948 stipulates that every child has the right to education at least in the elementary and fundamental stages. Independent African nations on becoming aware of the United Nations Declaration of Human Rights of 1948 and the fact that large investment would pay off in economic terms started increasing the intake of school pupils at the primary level of education (Antwi, 1992).

The Accelerated Development Plan of education was introduced in Ghana in 1951 to make education available to every child of schoolgoing age to meet the increasing demand for education. Despite these laudable efforts of the government, many children either never attended school or became dropouts very early at school. One reason was that most parents preferred their male children helping them on their farms to "wasting" their time in school. Girls were also kept at home to act as baby-minders, house-helps and also to sell in the market. Some parents also feared the girls would become pregnant if they associated themselves with boys outside the homes (Oppong, 1977). The end result of children either not going to school or dropping out of school was the increase in adult illiteracy some years later.

\section{Beginning of A dull Literacy in Ghana}

Adult Literacy Campaign in Ghana was started in 1948 by Dr. Frank Laubach of the World Literacy and Christian Literature (Aggor, 1992). During the same time, the Colonial Office Advisory Committee on Education presented a report entitled "Mass Education in Africa Society" which emphasised the attainment of literacy as a necessary condition for socioeconomic improvement. The government continued with the Adult Literacy Programme till it handed over the governance of the country to the Convention People's Party. Later the Department of Social Welfare and Community Development took over the responsibility of organising 
literacy classes for illiterates. By 1954 adult literacy programme had spread all over the country. The literacy classes collapsed in 1961 because what was learnt was meaningless, as it did not help the learners in solving any problem (Haggar, 1992). The programme finally discontinued after the overthrow of the government. By 1984 there were about 5.6 million adult illiterates (Ministry of Education [MOE], 1992).

In 1987, the government of the erstwhile Provisional National Defence Council fully re-vitalized adult literacy by establishing the Nonformal Education Division (NFED) within the MOE. It was the latest attempt at eradicating illiteracy among approximately 6 million adult illiterates. That was the time when the New Education Reforms (NER) programme was launched by the government with the view to utilizing all human resources of both the literate and illiterates for national development.

The NFED was charged with the responsibility of improving the quality of life of the poorest Ghanaian especially those in the rural areas. This was to be done through the provision of basic literacy and numeracy skills to facilitate the acquisition of new knowledge and the development of positive attitude towards the environment (MOE, 1992). Thus the NFED is concerned with teaching adult illiterates reading, writing and numeracy that reflect learners' everyday activities. This is functional literacy.

\section{Objectives of the Functional Literacy Programme in Ghana}

The policy document on the Functional Literacy Programme in Ghana outlines four objectives of the programme (MOE, 1992). The objectives are as follows:

1. To enable the participants better meet their personal or social needs through enhancing their abilities to deal competently with everyday life in a literacy community.

2. To equip learners with the knowledge, attitude and skills that will enable them raise the quality of lives in their communities.

3. To enable learners improve upon their occupational skills through functional literacy.

4. To broaden the reading interests of learners and establish an attitude of reading for pleasure through the provision of followup literacy materials. 


\section{Statement of the Problem}

Adult literacy was undertaken by many developing countries between 1950 and 1980 (Abadze, 1994). The "Education for All Conference" of 1990 was the main impetus for the campaign for adult literacy after that time. The conference appealed to international financial agencies to come to the aid of adult literacy programmes in terms of funding. This yielded some positive results; for instance in 1993 Ghana, Indonesia and Bangladesh were given \$US 27.4 million, \$US 13.9 million and \$US 25.0 million, respectively by various international financial organizations (Abadze, 1994). Between 1992 and 1995 the NFED, Ghana was offered \$US 0.6 million, \$US 17.4 million, \$US 2.9 million and \$US 9.9 million by the United Nations Children and Education Fund, the World Bank, the Government of Norway and the Government of Ghana, respectively (MOE, 1992).

Most studies conducted on adult literacy present positive outcomes to suggest that huge funds have been put to good use. Cunnings (1992) asserts that the level of literacy acquired during adult literacy classes tend to show that the learners could read and write. Studies in Tanzania show that $75 \%$ of participants of literacy classes retain literacy (Semali, 1991). In Ghana participants of the literacy classes could read and write (MOE, 1997; Addo-Adeku, 1992; Aggor, 1992).

Available studies conducted in Ghana on adult literacy (MOE, 1997; Addo-Adelcu, 1992; Aggor, 1992) all focus more on the continuinglearners than those who have already graduated from the literacy classes. Very few studies therefore seem to have been conducted on the beneficiaries of the functional literacy classes in Ghana. The question that must be answered therefore is whether the Functional Literacy Programme in Ghana is really having the desired positive impact on the socio-economic lives of the beneficiaries of the programme.

In line with the problem stated, the study was designed to ascertain the extent of impact of the Functional Literacy Programme on the living conditions of beneficiaries.

\section{Research Hypotheses}

The following null hypotheses were raised to pilot the study:

$\mathrm{H}_{\mathrm{o}}$ : There is no relationship between participation in functional literacy classes and improvement in socio- economic lives.

$\mathrm{H}_{\mathrm{o}} 1$ : There is no relationship between participation in functional literacy classes and ability to read, write or, perform numerical calculations. 
$\mathrm{H}_{0}$ 2: There is no relationship between participation in functional literacy classes and improvement in health related issues.

\section{Literature Review}

Need for Literacy in Attaining the Goals of Fundamental Education

Literacy, the ability to communicate in print, is a very important aspect of learning worldwide (Mpofu, 1995). Bhola (1984) has observed that literacy is the acquisition of the knowledge and skills in reading and writing that enables a person to engage himself effectively in any activity. Reading and writing of letters, signing of cheques, observing danger warnings in the street and at work places and reading of books are some of the activities identified by Bhola (1984). The definition of Coombs (1985) is centred on development. Coombs (1985) has emphasized that

Literacy could liberate the poor and educated people everywhere from ignorance, diseases and hunger. Moreover, the spread of literacy would not only improve the lot of the needy but work wonders for each nation's over all social and economic development (p. 15).

Davidson (1990), on the other hand has defined literacy in terms of its contribution to society. He has argued that literacy is necessary for the individual to enable him to be very effective in economic, socio-political, educational, cultural and environmental issues. Looking at literacy differently, since anyone who has not been given the opportunity to learn to read and write cannot lead a full individual and social life. The Ghana Statistical Service (as cited in Osci, 1992) has defined a literate person as one who "can read and write with understanding, a letter in any language".

The MOE (1992) has also defined literacy in terms of community development. The ministry has stated that a person is literate when he acquires knowledge and skills, which enable him to engage in all those activities for which literacy is required for effective functioning in his group and community and those attainments in reading writing and arithmetic, which make it possible for him to continue to use these skills towards his active participation in the life of his community. What is implicit here therefore is that literacy is defined by various people and bodies depending on their perspectives. Addo-Adeku (1992) is therefore right in his assertion that "the concept literacy has not yet got a universally accepted definition". 


\section{Values inherent in Literacy}

There are lots of benefits that can be derived from literacy. Gray (1990) has identified six values, which give a literate person an advantage over one who is not. The values are as follows:

1. Literacy helps to meet many of the practical needs of daily life.

2. Literacy helps in improving the standard of living by obtaining valuable printed information relating to health, sanitation, production, selection and preparation of food, childcare and home management.

3. Literacy increases economic status through engaging in vocations, which require knowledge of reading and writing.

4. Literacy enables one to take part in many individual and group activities that involve reading and writing and this helps to gain social prestige.

5. Literacy enables one to learn about community activities through reading.

6. Literacy enables one to meet one's civic obligations such as voting.

The MOE (1992) also outlined thirteen advantages of literacy. The following are the advantages:

1. Literacy enables individuals to read road signs, house numbers and so on, and therefore individuals can find their way around more easily even in strange places

2. Literacy enables individuals to read instructions given on medicines and drugs, and therefore avoid mistakes that could lead to disaster.

3. Literacy enables people to know what is happening in other parts of the country and in the world and this leads people to become enlightened.

4. Literacy helps people to know the prices of goods when they enter big stores and supermarkets.

5. Literacy helps individuals in big towns to identify buses and trains they must use on their journeys.

6. Literacy enables farmers and workers to read scales and instructions. This helps them to avoid mistakes and also to avoid being cheated.

7. Literate parents are able to help their children with their school work. 
8. Literate persons are able to communicate their secrets to people in distant places through writing their own letters, and are therefore able to keep secrets.

9. Literate people are able to fill forms on their own, such as when they are looking for jobs, or when they are at the bank or the post office, at election time, etc.

10. Literacy makes workers more efficient by helping them to read the right time and use instruments.

11. Literacy enables citizens to read and understand policies of the government; it also allows them to participate in government.

12. Literacy makes people more aware, enlightened and confident and therefore more capable of discussing their own problems and taking their own decisions.

13. Literacy opens the door for further education and individual advancement. What can be said therefore is that the values inherent in literacy cannot be over emphasized since they enhance improvement in the standard of living of the individual and society at large.

\section{The Concept of Functional Literacy}

While fundamental education is concerned with the teaching of only reading, writing and arithmetic, functional literacy goes beyond. Functional literacy which has become topical in Ghana is derived from the word "function" which has several meanings in both social and scientific usage. Addo-Adeku (1992) has defined functional literacy as

A built-in mechanism which uses the participating techniques in dealing with identifiable groups. Such groups would need the skills of reading, writing and reckoning to enable them to perform effectively in their general life style (p. 11).

By this definition a functionally literate person should be able to take part in all social and cultural activities, making use of his literacy. In Addo-Adeku's (1992) view, a functionally literate person should be able to read and write and understand simple statements relating to his daily activities, work environment and his community. In the same vien, UNESCO (1978) has defined a functionally literate person as one who is able to engage in all those activities in which literacy is required for effective functioning of his group and community. He or she should also 
continue to use reading, writing and arithmetical calculations for his own advancement and for the development of his community.

In its original formulation, functional literacy is not restricted to reading, writing and reckoning. It should also contribute to the preparation of the individual for social, civic and economic roles (Dorvlo, 1992). Hagar (1992) has stressed that functional literacy aims to promote a holistic approach to development with man as a whole person in the centre. Freire (1992) has noted that functional literacy should create the awareness of the living conditions of learners and therefore should lead to solving common problems facing learners.

The MOE Ghana (1992) has recognised the contribution of functional literacy as having to do with learning to read and write about the activities we everyday engage in our lives, problems and needs. Functional literacy is therefore based on the learner's problems, needs, interests and aspirations with the hope of finding solutions to them. Functional literacy enables learners to share information and new ideas. It also helps in the planning of activities within the learners' localities. The United States Government (as cited in UNESCO, 1983) has defined functional literacy as "possession of the essential knowledge and skills that enables an individual to function in his/her environment at home, in the community and in the work place" (p. 4).

Functional literacy is therefore the difference between an individual's current level of literacy and the level demanded by his environment.

\section{Research Design}

A descriptive analytic research design was used. This design was used to obtain data concerning the current state of a phenomenon. The design points to the determination of the nature of an ongoing situation as it stands at the study.

\section{Population and Sample}

The target population comprised all the beneficiaries of the Functional Literacy Programme in the Agona District of Ghana while the accessible population was made up of all the beneficiaries of the Functional Literacy Programme in the Agona District who, at the time of the study, were still residing in the catchment areas where they attended their classes. These beneficiaries were mostly farmers and traders.

A sample size of 100 respondents was used for the study. The respondents were randomly selected by the proportional stratified random sampling technique from all the 20 literacy classes in the Agona 
District. This is because some of the classes had more beneficiaries than others.

\section{Research Instrument}

Interview guide was the main instrument used for the study. The interview guide was mostly of the checklist type. Some open-ended items were however included. There were also some observations on the ability of respondents to read, write and do some numerical calculations. These multi-techniques were used in order to capture a more reliable picture of the phenomenon.

\section{Data Collection Procedure}

Data was collected personally by the researcher with the assistance of the facilitators of the various functional literacy classes. This involved visiting the respondents personally and explaining the purpose of the study to them and then administering the interview guide.

\section{Data Analysis Procedure}

The Pearson Product Moment Correlation (PPMC) coefficient statistics was used in analysing the findings of the study. This was used to show the various degrees of relationships that exist between the variables of the hypotheses postulated for the study. All the null hypotheses were tested at .05 alpha level.

\section{Findings}

The results of the study are presented in accordance with the earlier stated research hypotheses as follows:

\section{Main Hypothesis}

There is no significant relationship between participation in functional literacy classes and improvement in socio-economic lives. 
Table 1: Test of relationship between participation in functional literacy classes and improvement in socio-economic lives.

\begin{tabular}{|l|c|c|c|c|c|c|}
\hline \multicolumn{1}{|c|}{ Variable } & N & df & Cal.r & $\begin{array}{c}\text { Critical } \\
\text { r }\end{array}$ & Level & Comment \\
\hline $\begin{array}{l}\text { Participation in } \\
\text { functional literacy } \\
\text { classes and } \\
\text { improvement in } \\
\text { socio-economic lives. }\end{array}$ & 100 & 98 & 0.492 & 0.195 & 0.05 & $\begin{array}{c}\text { Ho } \\
\text { rejected }\end{array}$ \\
\hline
\end{tabular}

The result in Table 1 indicates that the calculated value of $\mathrm{r}$ is 0.492 and this is greater than the critical $r$ value which is 0.195 , hence we reject the null hypothesis. This implies that there is a relationship between participation in functional literacy classes and improvement in socio economic lives.

\section{Hypothesis I}

There is no significant relationship between participation in functional literacy classes and ability to read, write or do numerical calculations.

Table 2: Test of relationship between participation in functional literacy classes and (a) ability to read, (b) ability to write and (c) ability do numerical calculations

\begin{tabular}{|c|l|c|c|c|c|c|c|}
\hline & \multicolumn{1}{|c|}{ Variable } & N & df & Cal.r & $\begin{array}{c}\text { Critical } \\
\text { r }\end{array}$ & Level & comment \\
\hline a & $\begin{array}{l}\text { Participation in } \\
\text { function literacy } \\
\text { classes and ability } \\
\text { to read. }\end{array}$ & 100 & 98 & 0.220 & 0.195 & .05 & $\begin{array}{c}\text { Ho } \\
\text { rejected }\end{array}$ \\
\hline b & $\begin{array}{l}\text { Participation in } \\
\text { functional literacy } \\
\text { classes and } \\
\text { ability to write }\end{array}$ & 100 & 98 & 0.212 & 0.195 & .05 & $\begin{array}{c}\text { Ho } \\
\text { rejected }\end{array}$ \\
\hline c & $\begin{array}{l}\text { Participation in } \\
\text { function literacy } \\
\text { classes and ability } \\
\text { to do numerical } \\
\text { calculations }\end{array}$ & 100 & 98 & 0.423 & 0.195 & .05 & $\begin{array}{c}\text { Ho } \\
\text { rejected }\end{array}$ \\
\hline
\end{tabular}


The result in Table 2 shows that the calculated value of $\mathrm{r}$ is 0.220 for the variable, participation in functional literacy classes and ability to read. This is greater than the critical $r$ value which is 0.195 , hence we reject the null hypothesis. This implies that there is a relationship between participation in functional literacy classes and ability to read. Also, 0.212 is the calculated value of $r$ for the variable, participation in functional literacy classes and ability to write. This is greater than the critical $r$ value 0.195 and therefore the null hypothesis is rejected. This shows that there is a relationship between participation in functional literacy classes and ability to write. Furthermore, the table indicates that the calculated value of $\mathrm{r}$ for the variable, participation in functional literacy classes and ability to do numerical calculations is 0.423 which is greater than the critical $r$ value 0.195 . The null hypothesis is therefore rejected. This also implies that there is a relationship between participation in functional literacy classes and ability to read.

\section{Hypothesis 2}

There is no significant relationship between participation in functional literacy classes and improvement in health related issues.

Table 3: Test of relationship between participation in functional literacy classes and improvement in health related issues.

\begin{tabular}{|l|c|c|c|c|c|c|}
\hline \multicolumn{1}{|c|}{ Variable } & N & df & Cal.r & Critical r & Level & Comment \\
\hline $\begin{array}{l}\text { Participation in } \\
\text { functional literacy } \\
\text { classes and }\end{array}$ & 100 & 98 & 0.718 & 0.195 & .05 & $\begin{array}{c}\text { Ho 2 } \\
\text { rejected }\end{array}$ \\
$\begin{array}{l}\text { improvement in } \\
\text { health related issues }\end{array}$ & & & & & & \\
\hline
\end{tabular}

It is evident from Table 3 that the calculated value of $\mathrm{r}$ is 0.718 and this is greater than the critical $r$ value which is 0.195 , hence we reject the null hypothesis. This implies that there is a relationship between participation in functional literacy classes and improvement in health related issues.

\section{Discussions}

The results of this study have revealed a major issue that has implication for the organisation of functional literacy in Ghana. It is the link between functional literacy and development. The findings of this study have revealed the "functionality" of the functional literacy classes. The 
beneficiaries of the functional literacy classes were able to read, write and calculate, and these were used to improve their social and economic lives. This is in conformity with the views of Addo-Adeku (1992), Dorvlo (1992), Freire (1992) and Merrill (1988) that functional literacy could be used to improve social, economic and environmental problems. A positive relationship could therefore be said to be existing between functional literacy and development.

This issue has implications for the organization of functional literacy in Ghana. Dorvlo (1992) has further emphasised that If functional literacy aims at preparation for political, socio - culture and economic roles, then the term development should be discussed politically, socially, economically and in any other way considered relevant. Okonjo (1986) has also stressed that if there is to be development, the amount of violence, poverty, repression and environmental deterioration in a nation must diminish. That is, there should be peace, greater economic well being, more social justice and better ecological balance. Development has also been defined by Dorvlo in terms of political, socio - culture and economic, According to Dorvlo, the term development can politically be referred to the preparation of people for intelligent participation in political process. In terms of socio - culture, the term refers to the process of helping the individual to avoid outmoded traditions and superstitions. Dorvlo (1992) has also said the term economically involves the accumulation of capital and its effective utilization to achieve and improve a balanced economy. Green (1977) on the other hand has viewed development in terms of the satisfaction of fulfilment of common or basic human needs, which include the following needs:

I. Personal consumer goods like food, clothing and shelter.

2. General access to physical and social services such as water and prevention of curative medicine.

3. Employment of individuals and earning sufficient income so as to benefit from the supply of goods and services.

4. Provision of physical human and technological infrastructure.

5. Mass participation in decision making.

Taking into consideration the findings of this study and the various views on functional literacy and also of development, there has been considerable amount of evidence to suggest that functional literacy makes significant contributions to social, economic, and political development of the individual and society. Functional literacy emphasises among other 
things, reading, writing and arithmetic. The ability to read, write and do some numerical calculations could enhance development for instance, for one to be able to identify his hospital card in order to attend the hospital could promote his good health. Normal occupation could therefore be pursued without much health problems. Productivity and income levels could rise, leading to an increased purchasing power. Fundamental human needs could therefore be purchased and standard of living is raised. This could lead to social and economic development of the individual as explained by Green (1997), Dorvlo(1992) and Okonjo (1986).

The ability to record the names of debtors and creditors, the ability to use calculator to calculate profit or loss of trading activities, and transact business at the bank very quickly, among others, could help improve trading activities and bring about efficiency. Profit could be maximized, savings encouraged and investment made to $\bullet$ expand trading activities. More profits could increase the purchasing power and therefore the basic fundamental human needs could be met to raise the standard of living, which could lead to social and economic development of the individual.

Functional literacy also teaches the control and prevention of some common diseases. Good health could enable one to practice his normal occupation devoid of any health problems. With the requisite knowledge on how to maintain healthy family, control and prevention of common diseases and environmental cleanliness, the individual could become healthy to pursue his normal occupation. Productivity could be increased and the level income raised. This could increase purchasing power and increase the purchase of basic needs to raise standard of living. Social and economic development therefore could take place (Dorvlo, 1992; Green, 1997).

\section{Conclusion}

The conclusion drawn from the findings of the study revealed the following:

- There is a positive relationship between participation in functional literacy classes and ability to read.

- There is a low positive relationship between taking part in functional literacy classes and ability to write.

- $\quad$ There is a positive relationship between participation in functional literacy classes and to do some numerical calculations. 
- $\quad$ The relationship between participation in functional literacy classes becoming conscious of the need to improve upon health status is highly positive.

\section{Recommendations}

- $\quad$ Even though it has been revealed that the functional literacy classes help beneficiaries to improve upon their health status, organisers of the literacy classes should emphasise the causes and prevention more than the control of common tropical diseases.

- It has been established that even though learners of the literacy classes can read to an appreciable level, their writing ability is nothing to write home about. It is therefore suggested that facilitators of the functional literacy classes should do well to improve upon their pedagogical skills to help address this problem. This can be achieved through regular in-service training, adequate motivation and provision of relevant instructional materials.

- There are many illiterates who have either not heard of the functional literacy classes or have heard of it but are reluctant to enrol in the classes. It is recommended therefore that television and local FM radio stations within the localities in which the classes are located should be used by facilitators to advertise the importance of joining the literacy classes so as to enrol more illiterates.

\section{References}

Abadze, H. (1994) Adult literacy: Problem-ridden area. World Bank Discussion Papers 2 (3), 410-420

Addo-Adeku, K. (1992) A case study of functional literacy programme in the Ga district, greater Accra region of Ghana. Ghana Journal of Literacy and Adult Education. 1(2), 167-182.

Aggor, R. K (1992) Developing relevant post-literacy curricular for neoliterates in Ghana. Ghana Journal of Literacy and Adult Education. 1(2), 149-165.

Antwi, K. A. (1992) Education, society and development in Ghana. Accra Unimax PublishersLimited.

Bhola, H.S.,(1984) World trends and issues in adult education. London: Biddies Ltd.

Coombs, P.H.(1985) The world in crisis in education: the view from the eighties. Trenston: Oxford University Press

Cunnings, B. (1992) Adult and literacy New York. Haper and Row Publishers.

Davidson K., (1990) the Adult Learner. New Jersey: prentice Hall. 
Dorvlo, L. T. K.,(1992) Some fundamental issues in functional literacy. Ghana Journal of Literacy and Adult Education. 1(1), 15-28.

Freire, P. (1992) Cultural action for freedom. London: Penguin.

Gray,W.S.(1990) Teaching of reading and writing: An international survey. Chicago: Scott Foresman and Co.

Green, R H. (1977) Adult education and national development: Notes towards an integrated approach. Bonn: German Adult Education Association Inc.

Merril, P. (1988) Guidelines for adult literacy. New York: Rowland Press.

Ministry of Education (1992) National functional literacy campaign for social change. Facilitators' manual. Accra: Max Associates Ltd.

Mpofu, S. T. (1995) The outcome and shortfall of the adult literacy and post-literacy project of Zimbabwe 1987-1991. Zimbabwe Journal of Educational Research. 1(1), 85-113

Okonjo, C. (1986) The concept of development. In Brown C.K.(Ed), 1-25, Rural development in Ghana. Accra: Ghana Universities Press.

Oppong, C. (1997) Sex roles, population and development in West Africa. West Africa Policy related studies on work and demographic issues. London: Curray Ltd.

Semali, K. (1991) Adult education in Tanzania. McGraw-Hill Company of Canada.

Thompson, A.R. (1981) Education and development in Ghana. London: Macmillan Educational Ltd.

UNESCO (1983) Summary of the international conference on adult education. Geneva: UNESCO. 